\title{
骨組構造の爆破解体解析・実験システムの開発 \\ DEVELOPMENT OF ANALYTICAL AND EXPERIMENTAL SYSTEMS FOR BLAST DEMOLITION OF FRAMED STRUCTURES
}

\author{
磯部 大吾郎*，江口正 史**，今 西 健 介**，佐々木 嗣音** \\ Daigoro ISOBE, Masashi EGUCHI, Kensuke IMANISHI \\ and Zion SASAKI
}

\begin{abstract}
A controlled explosion technique using high explosives has been developed in recent years. Although the blast demolition technique increases work efficiency, it poses a high risk of damaging neighboring buildings, especially in urban areas. It also requires high levels of knowledge and experience, which are very difficult for general engineers to master. To familiarize the demolition technique among engineers, numerical assumptions using computational analysis in devising the blast demolition have become essential in ensuring the success of this technique. One of the objectives of this study is to perform some blast demolition analyses of framed structures using a dynamic finite element code, whose validity against impact collapse problems of large-scale structures has recently been developed and verified. Another objective of this study is to develop a mimic demolition experimental system that uses magnetic devices to express member fracture caused by explosion. The magnetic field of the devices is controlled by a blast interval controller and power switches, which control the binding of each connection in the framed structure. The experimental system does not use explosives or any such dangerous substances, and multicycle use is possible. An experiment is carried out to compare quantitatively with the numerical result.
\end{abstract}

Keywords : Blast demolition, Framed structures, ASI-Gauss technique, Finite element method, Demolition experiment 爆破解体, 骨組構造, ASI-Gauss 法, 有限要素法, 解体実験

1. はじめに

欧米などでは近年, ダイナマイトの発破により多層構造物を取り 壊す，いわゆる爆破解体が盛んに行われている．重機や人間の手に よって解体する従来の工法と比べて工期が短く，安全性や経済性の 面で有利な点が多い．しかし，このような爆破解体作業には，特に 都市部では周辺構造物に被害を与えないよう細心の注意を持ってあ

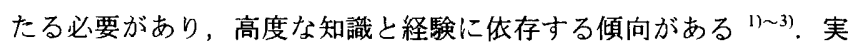
際に日本では，筑波科学万博会場や琵琶湖々畔の古ホテルの取り壊 しなど，その適用例はごく少数に限られている．爆薬の配置箇所や その量はもとより，発破順序やタイミングに関するノウハウを広く 共有できれば，爆破解体技術のさらなる普及が見込まれる．このノ ウハウの共有化には，解体実験の繰り返し実施による情報収集のみ ならず，建物の崩壊現象を定量的に扱うことが可能な数值解析手法 の開発が必要であると考える.

今日までに，建物の崩壊現象を解析した例がいくつか報告されて いる. 中でも, 個別要素法 (DEM) ${ }^{4)}$ や不連続変形法 (DDA) ${ }^{5)}$ は その適用範囲が多岐に渡っており, 建物の地震崩壊解析 ${ }^{6}$ や岩盤崩 落解析 》などでは多くの成果が出ている. しかし，その数值モデル の特性上, 3 次元建物モデルでの弾性状態から塑性, 破断状態まで に渡るシームレスな解析は現状では困難である。

本研究では，爆破解体現象を定量的に采統立てて把挃するために， 弾性状態から塑性, 破断状態までシームレスに解析可能な有限要素 解析手法を構築し，さらには，電磁デバイスを用いた再利用可能な 解体実験システムを開発することを目的とする.

解析手法には, WTC ビルの飛行機衝突解析 ${ }^{8)}$ などで使用実績の
ある ASI-Gauss 法 ${ }^{99}$ を適用する. ASI-Gauss 法は, 要素内の数值積 分点を部材性状に合わせて順応的にシフトすることで, 計算コスト を低く抑えることが可能な順応型 Shifted Integration 法 (ASI 法) ${ }^{10)}$ 〜13)をさらに改良した手法である. ASI-Gauss 法では，2 つの線形チ モシェンコはり要素をサブセット要素として考え, そのガウス積分 点に相当する位置に応力評価点を配置するように数值積分点をシフ トすることで, 弾性変位解の精度を向上させている．また， ASI 法 と同様に，積分点のシフトと同時に断面力を解放することで破断を 表現し，幾何学的な位置関係に基づいて要素間をギャップ要素で拘 束し，接触を表現可能としている. 本研究では，ASI-Gauss 法を用 いて骨組構造の爆破解体解析を実施し, 発破条件の相違による崩壊 モードへの影響を調べ, 解析システムの有効性を検証した。

その一方で，アルミニウム角材の両端に電磁ホルダを取り付けた 構造部材を多数連結して骨組構造を組み上げ，制御装置により任意 の連結部の磁界を消滅させて発破を模擬し，解体現象を再現する実 験システムを開発した。発破間隔はPCで制御し, 発破箇所は磁界 切換えスイッチにより指定する.この実験システムは爆薬などの危 険物を使用せず，何度も再利用可能である．本研究では 6 層骨組構 造の解体実験を行い, 解析結果と定量的な比較を行った。

\section{2. 数值解析手法}

\subsection{ASI 法と ASI-Gauss 法}

ASI 法では，要素内に発生する塑性ヒンジの位置を正確に表現す るために，要素の弾塑性性状に合わせ数值積分点を順応的にシフト する. その結果，最小限の要素分割数で骨組構造の塑性崩壊荷重解
* 筑波大学大学院 助教授・博士 (工学)

** 筑波大学大学院システ公情報工学研究科
Dept. of Engineering Mechanics and Energy, Univ. of Tsukuba, Dr. Eng. Graduate School of Systems and Information Engineering, Univ. of Tsukuba 


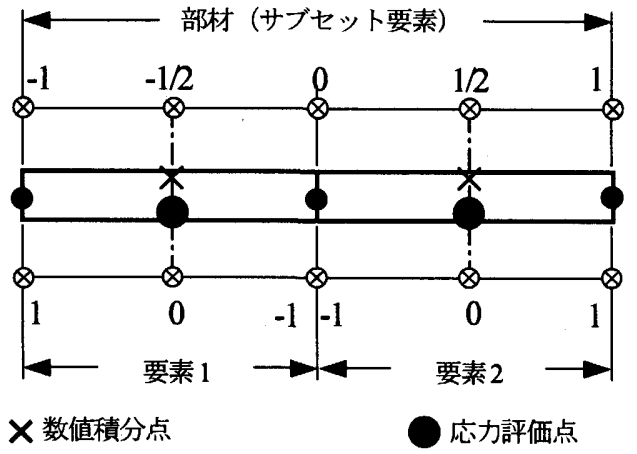

(a)ASI法

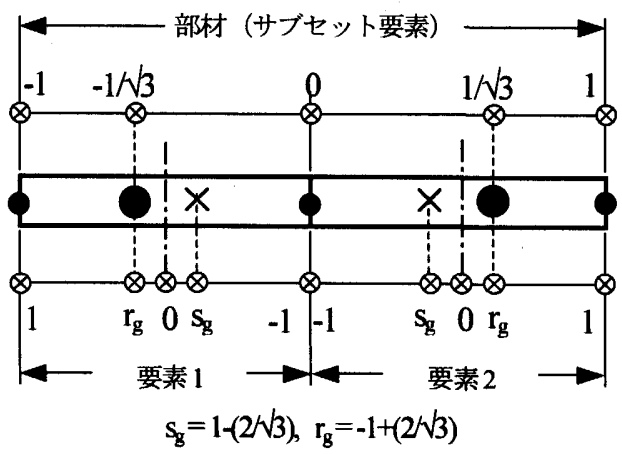

(b)ASI-Gauss 法

図 1 弾性域における数値積分点および応力評価点の位置

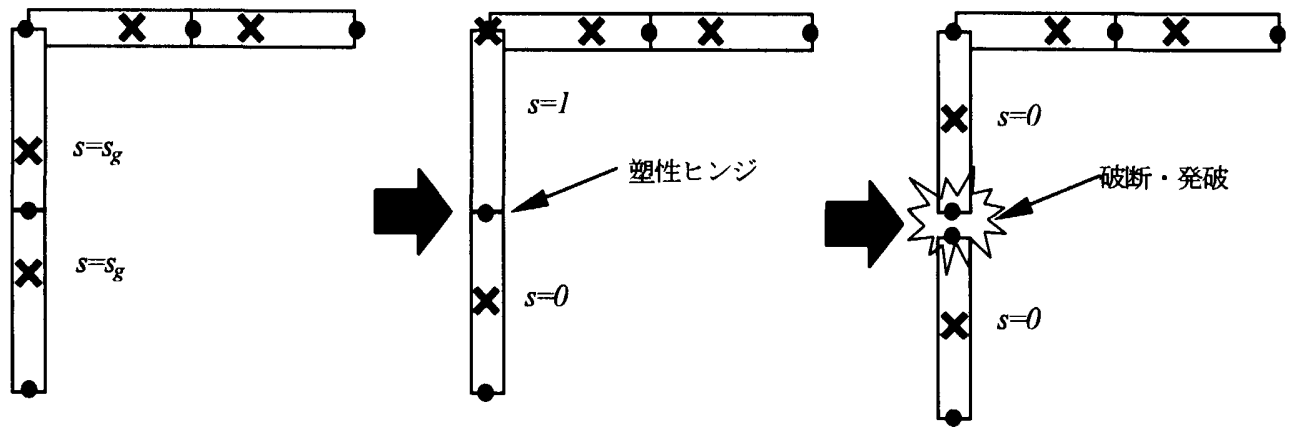

- 節点 $\quad$ 数値積分点

(a)弹性域

(b)塑性域

(c)部材破断

図 2 部材性状に応じた数值皘分点の配置（ASI-Gauss 法）

を求めることが可能となり，計算コストを従来のものより大幅に削 減することに成功した ることで部材端部の破断を表現し，デブリ衝突解析 ゆ队地震崩壊解 析 ${ }^{139}$ など，多くの不連続体解析に適用することが可能となった。 し かしその一方で, 最小限の要素分割を施すことで, 線形チモシェン コはり要素が 1 点積分法を使用することによる弾性変位解の精度低 下の影響が顕著となった。そこで，弾性変位解の精度向上を狙って ASI 法は改良され，ASI-Gauss 法が開発された ?. 以下に両解法の概 要を記す。

線形チモシェンコはり要素と物理的な意味が明確な剛体ばねモ デル（Rigid Bodies Spring Model, RBSM）のひずみエネルギ近似式 の等価性を考虑すると, はり要素の数值積分点位置 $\mathrm{s}$ と剛体ばねモ デルのばねの位置 $\mathbf{r}$ (すなわち塑性ヒンジ発生点位置もしくは応力 評価点位置）との関係式は次式で与えられる ${ }^{14}$.

$$
r=-s
$$

ASI 法および ASI-Gauss 法では, 要素内に全塑性断面の発生が判定 された瞬間に上式にしたがって要素の数值積分点をシフトし，応力 評価点の位置に塑性ヒンジを表現する．除荷が生じた場合には，そ の数值積分点は初期位置に戻される。ここで初期位置とは，要素が 弾性的に挙動する際の数値積分点位置である.このように，数値積 分点は要素の弹塑性性状に合わせ順応的にシフトされ, その結果, 最小限の要素数で塑性崩壊荷重の収束解を得ることが可能となった. ASI 法では, 数值積分点の初期位置として，1 点積分法に対する
最適な位置，すなわち要素中央点を採用する。これは，線形チモシ エンコはり要素ではいわゆる “Shear locking”を避けるために積分 次数を低減させ，1 点積分法を用いて低次の変位関数を評価するか らである.しかし，低次関数を用いると自ずと弾性変位解の精度が 覀くなり，特に部材当りの要素数が少ない場合にはその影響が影著 となってしまう。そこで, 部材を構成する2つの要素をサブセット 要素としてまとめ, 各々の要素の応力評価点位置がサブセット要 素のガウス積分点位置と一致するように，(1)式にしたがって数值 積分点を配置したのが ASI-Gauss 法である．実際には要素毎に 1 点 積分を行い，曲げ変形精度が保証された 2 点積分法の数值積分点位 置で応力とひずみを評価することで，弾性変位解の大幅な向上が 可能となった. 図 1 に, ASI 法および ASI-Gauss 法の弾性域におけ る数值積分点と応力評価点位置を示す. 図中， $s_{g}, r_{g}$ はそれぞれ ASI-Gauss 法における数值積分点位置および态力評価点位置である. また図 2 に,ASI-Gauss 法におけるそれぞれの部材性状に応じた数 值積分点位置を示す. ASI-Gauss 法では, 一方の要素で塑性ヒンジ の発生が判定されると, その要素の数值積分点のシフトに応じ, 同 一部材（またはサブセット要素）を構成するもう一方の要素では, 1 点積分法に適した位置（すなわち中央点）に数值積分点がシフト される.

\section{2 部材の断面力一変形過程}

本研究では，部材を完全弹塑性体と仮定し，その破断は，部材を 構成する 2 つの要素の曲率と軸ひずみを監視し, 次式のいずれかの 条件を満たした場合に判定するる. 


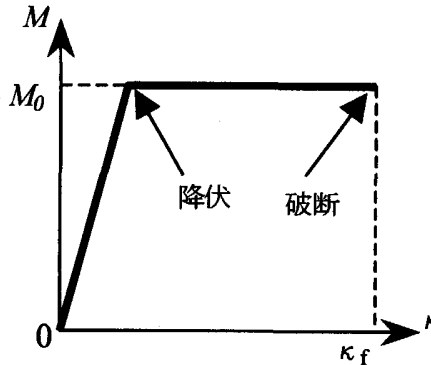

(a)曲げモーメントー曲率関倸

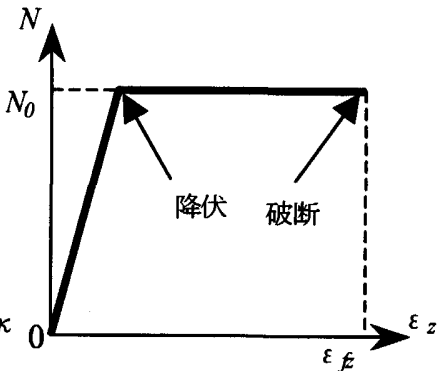

(b)引張軸力一引張軸ひずみ関係
図 3 部材の断面力一変形過程

$$
\left|\frac{\kappa_{x}}{\kappa_{f x}}\right|-1 \geq 0,\left|\frac{\kappa_{y}}{\kappa_{f y}}\right|-1 \geq 0,\left(\frac{\varepsilon_{z}}{\varepsilon_{f z}}\right)-1 \geq 0
$$

ここで, $\kappa_{x}, \kappa_{y}, \varepsilon_{z}, \kappa_{f x}, \kappa_{f y}$ と $\varepsilon_{f}$ 仗それぞれ $\mathrm{x}, \mathrm{y}$ 軸回りの曲 率，引張軸ひずみ，およびそれらの臨界值である. 図 3 に部材の断 面力一変形過程を示す．破断が判定されると，図 2(c)に示すように その断面に新しく節点が設けられ，要素の数值積分点は中央点にシ フトされる. 節点にかかる質量は，分離した節点に等しく分配され る. また，破断断面に作用していた断面力は，次ステップに瞬時に 解放される，一方，発破現象は，(2)式を用いることなく，指定し た節点を強制破断することによって表現する。
要素間の接触は幾何学的位置関係に基づいて判定し，該当する要 素の節点間を計 4 つのギャップ要素で接合して表現する．ギャップ 要素は軸剛性と曲げ剛性を有し，はり部材に使用した要素の性状を 持っ.ただし，強制破断箇所にこの要素を用いると，発破直後に完 全に結合してしまい，以後の倒壊挙動が再現できない，そこで，発 破点の柱間には，曲げ剛性の非常に小さいヒンジ要素 1 つを連結し， 特定の相対角度（本研究では $30^{\circ}$ ）に達すると削除した。

\section{3 数值例}

図 4 に示すような 5 層 5 スパン骨組構造に対し，2 種類の異なる 発破計画で ASI-Gauss 法による爆破解体解析を実施した。図中の数 字は発破順序を示す。発破間隔は $0.25 \mathrm{~s}$ とした。構造物の主な部材 パラメータは次の通りである. はり： $30 \mathrm{~cm} \times 30 \mathrm{~cm} \mathrm{H}$ 型鋼, スパ ン長 $6.0 \mathrm{~m}$, 破断臨界曲率 $3.2 \times 10^{-4} \mathrm{rad} / \mathrm{mm}$, 破断臨界引張ひずみ 0.17 , 柱 : $30 \mathrm{~cm} \times 30 \mathrm{~cm}$ 箱型鎆, スパン長 $3.6 \mathrm{~m}$, 破断臨界曲率 $5.3 \times 10^{-4} \mathrm{rad} / \mathrm{mm}$, 破断臨界引張ひずみ 0.17 , 鋼のヤング率 $214 \mathrm{GPa}$, ポアソン比 0.3. 本解析では, 床と壁の質量を部材密度に盛り込む 形で加えた．構造的な減衰は無視したが，解析を安定に行うために 数値減衰（Newmark の $\beta$ 法, $\delta=5 / 6, \beta=4 / 9^{19}$ ) を考虑した。時間 増分は $0.1 \mathrm{~ms}$ とした. Case 1 の発破計画では，構造物中央から順に 外側一向かって放射状に発破を繰り返し，内側へ構造物を倒すこと で解体を成功させることを目標としている，一方，Case 2 では，右 側の柱一列で発破が失敗した場合を想定している.

図 5 に解析結果を示す. Case 1 では, 周辺に部材が飛散すること

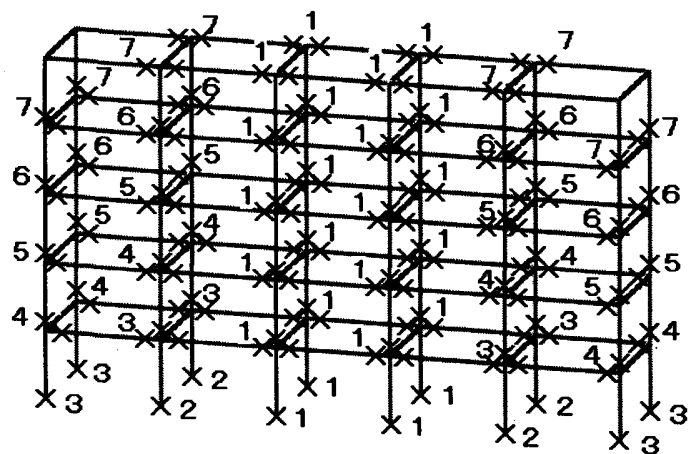

(a) Case 1
発破間隔: $0.25 \mathrm{~s}$

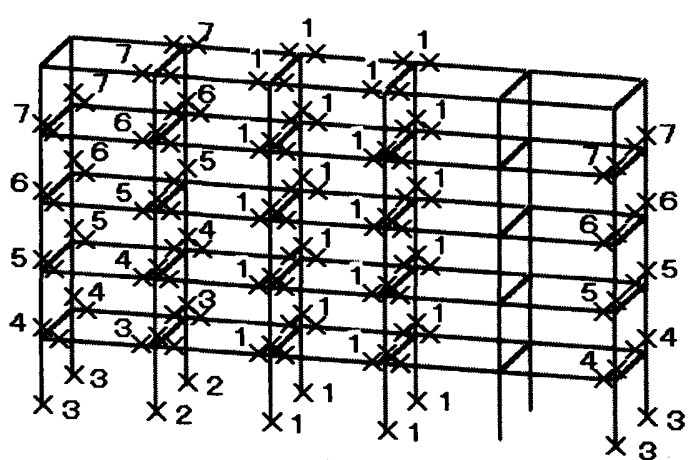

(b) Case 2

図45層 5 スパン骨組構造の発破計画

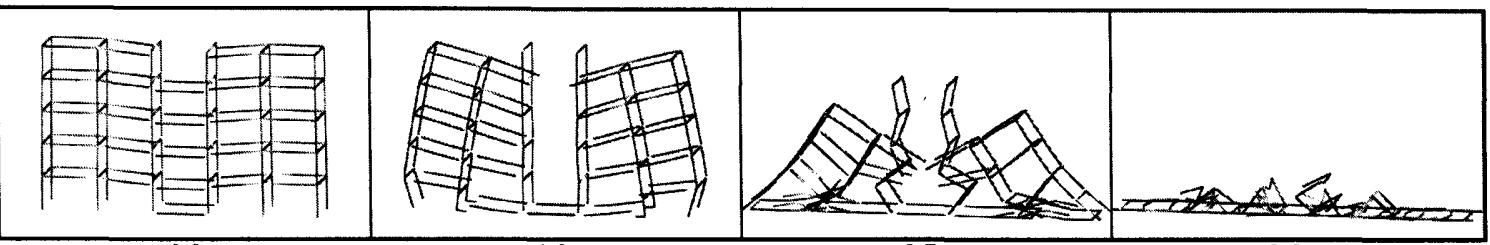

(a) Case 1

$3.6 \mathrm{~s}$

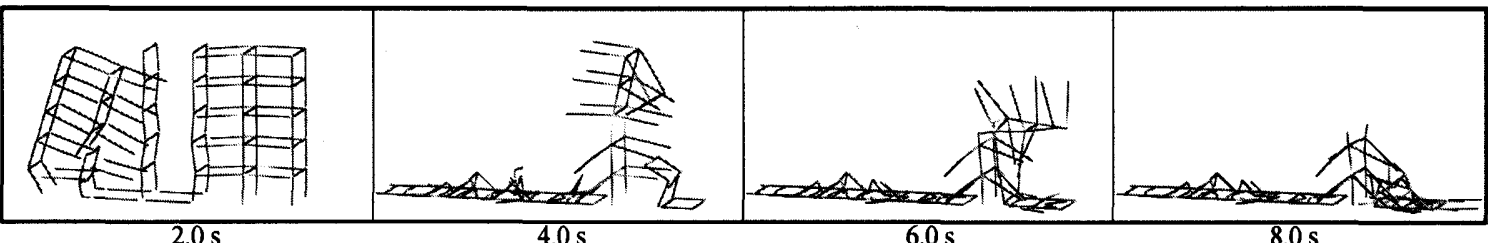

(b) Case 2

図 5 崩壊モードの相違 
なく, $3.6 \mathrm{~s}$ で構造物全体が中央に向かって完全に倒壊している. 強制破断筒所では，上層部の柱が階下の柱に接触して衝撃的な力を 作用させ，その後大きな曲げモーメントを受けて分離した。このよ うに，導入したギャップ要素が良好に機能し，また，重力を有効利 用した解体が実現できている様子が観察された。一方，Case 2 では， 発破に失敗した構造物の右側部分が，不安定にとどまった末に外側 へゆっくり倒壊している. 図 6には，Case 2 の数值例において，部 材変形に伴って自然に破断した筒所を示す。構造物左側は破断箅所 が少ないが，右側は発破が失敗したため無理な力が各所に作用し， 破断が多く生じていることが分かる．図中の要素 A（3 層目の柱要 素），要素 B（5 層目のはり要素）における断面力一ひずみ関係を それぞれ図 7, 図8に示す。、いずれも曲げモーメントの卓越により 曲率が增大し，破断に至っていることが分かる．軸力は要素 A で は圧縮方向，要素 B では引張方向ではあるが微小にしか作用しな いため，破断要因にはならなかった。他の破断筒所についても全て

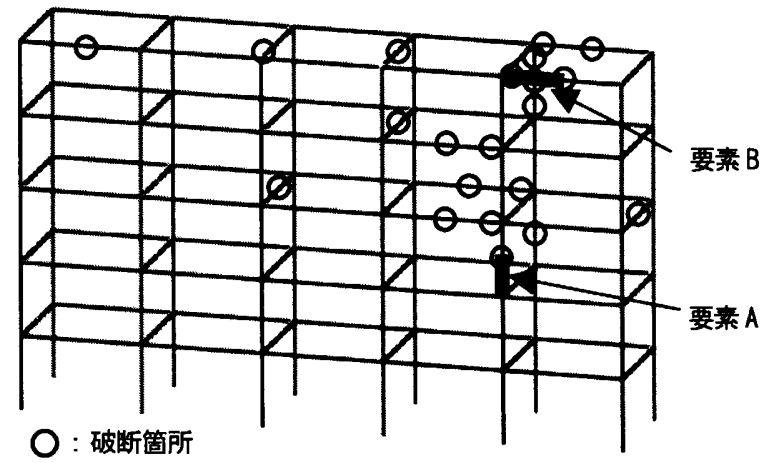

図 6 部材変形に伴う破断箇所 (Case 2)
曲率值で破断が判定されており，この場合には曲げ破壊型のモード となっていることが分かった．また，曲げモーメント一曲率関係に おいて断面力の低下が見られるのは, 他部材との接触により断面力

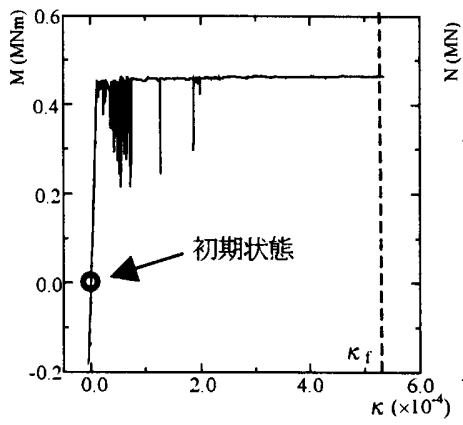

(a)曲げモーメント一曲率関倸

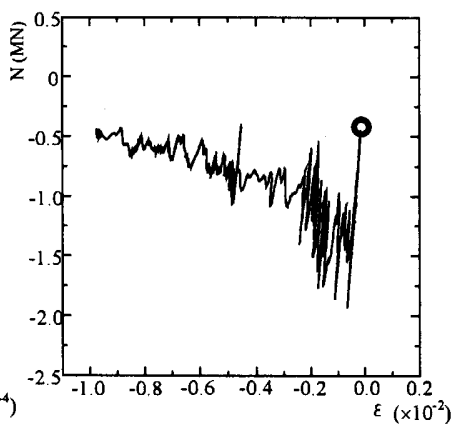

(b)軸力一軸ひずみ関倸
図 7 断面力-ひずみ関係 (要素 A)

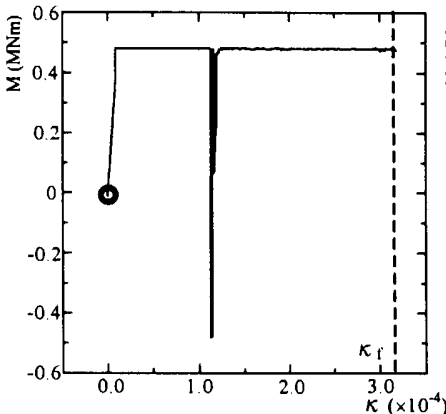

(a) 曲げモーメント一曲率関倸

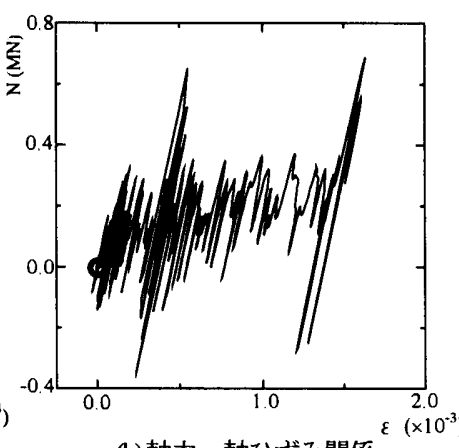

(b) 軸力一軸ひずみ関係
図 8 断面力ひずみ関係（要素B）

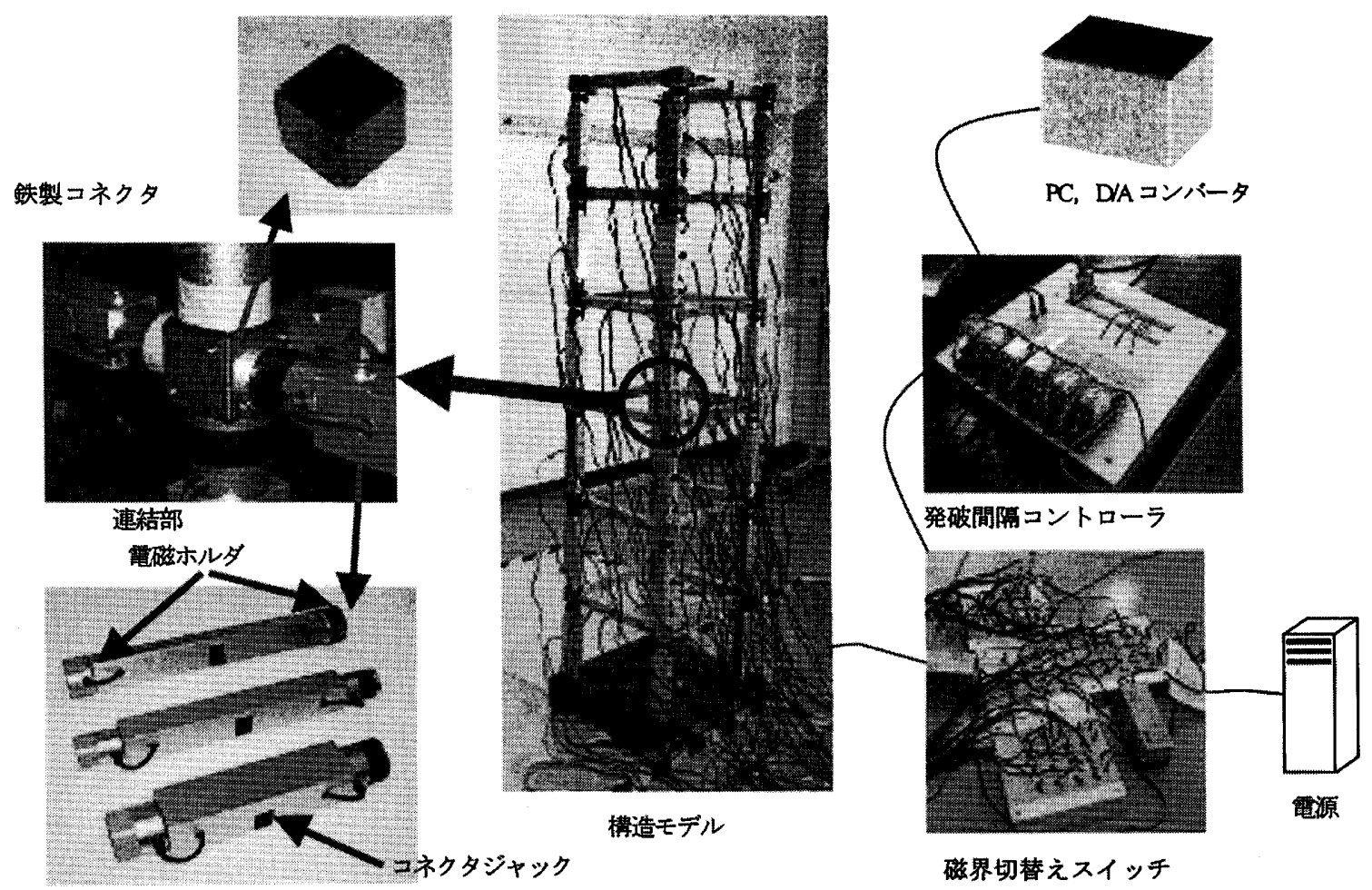

柱とはり部材

図 9 爆破解体実験システムの概要 


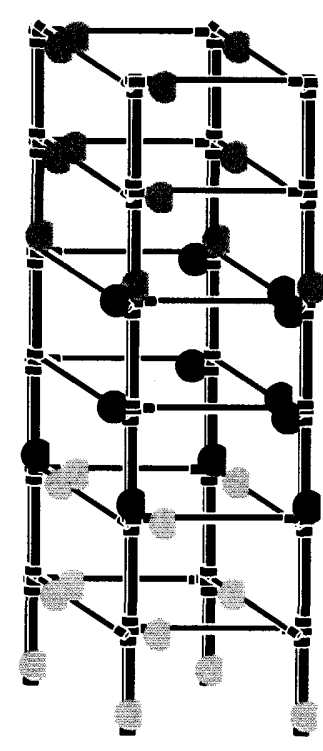

(a) 発破計画
発破順序

:1

6. $: 3$

発破間隔 : $02 \mathrm{~s}$

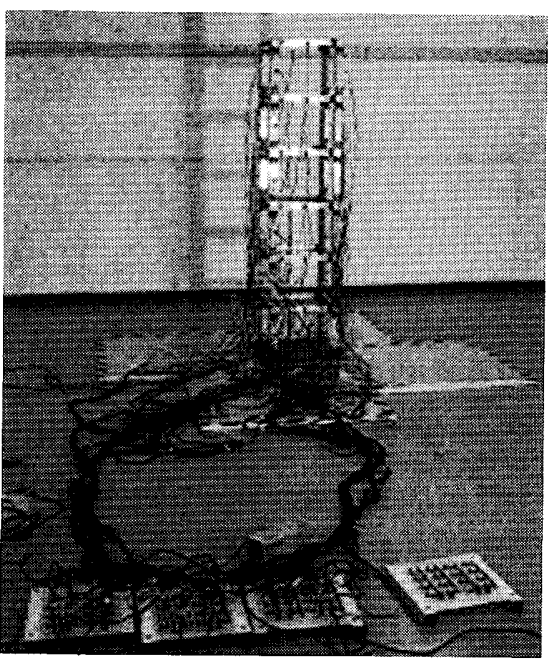

(b)組み上げられた実験システム

図 106 層構造物の発破計画

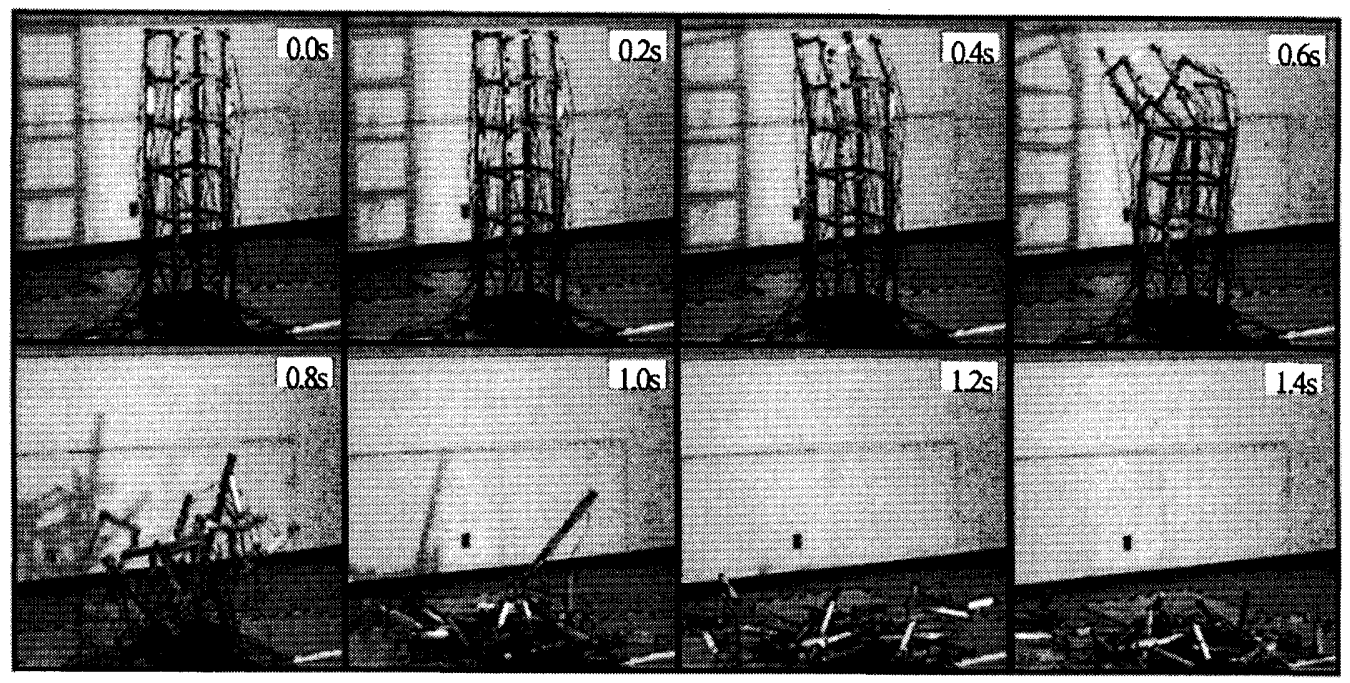

(a) 実験結果

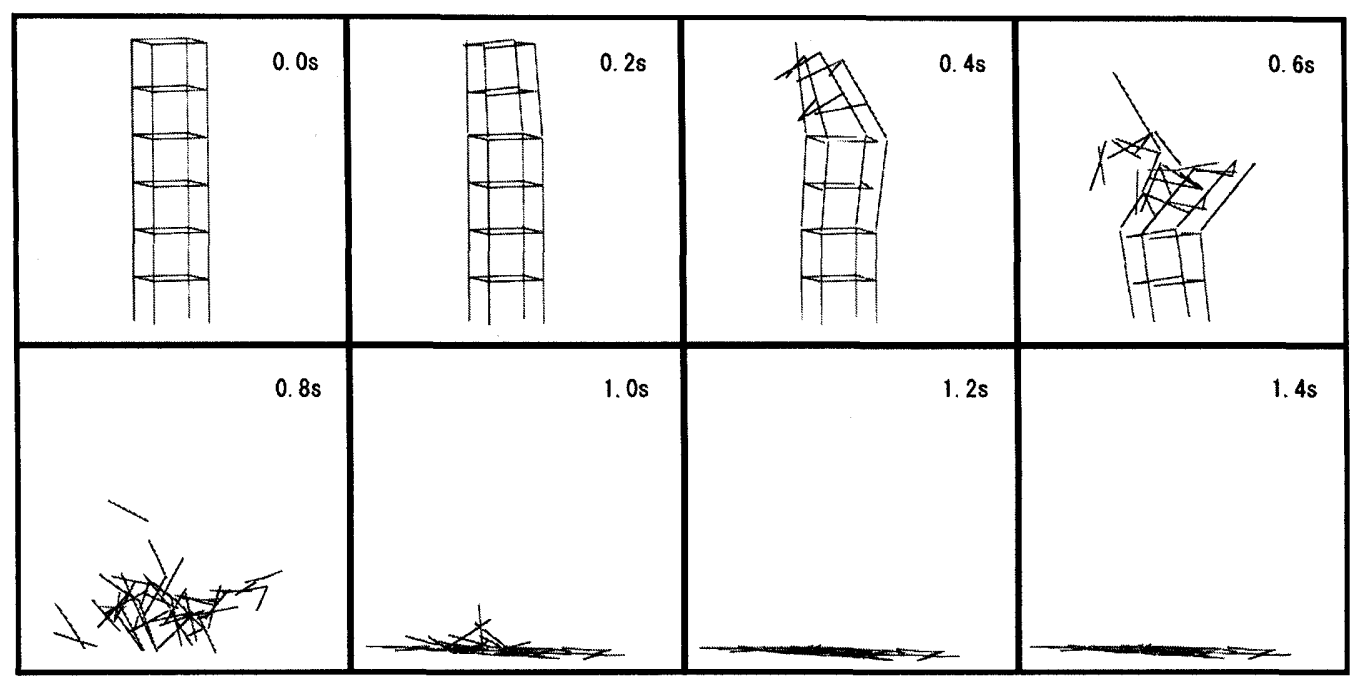

(b) 解析結果

図 116 層構造物の爆破解体 
分布が変わり, 除荷が生じたものである.

\section{3. 爆破解体実験}

数值解析結果と定量的に比較することを可能とするために，爆薬 などの危険物を使用せず，再利用が可能な爆破解体実験システムを 開発した. 図 9 にその概要を示す.アルミニウム角材の両端に電磁 ホルダ（KANETEC 社製, KE-4RA, 最大吸着力 $110 \mathrm{~N}$ (はり部 材），KE-4B，最大吸着力 $400 \mathrm{~N}$ (柱部材））を取り付け，その磁 界によって鉄製コネクタを介して他の部材と連結する. 電磁ホルダ に必要な電流は, 電源から電話線と 4 ピンコネクタジャックを介し て供給される. 電話線先端のピンは，部材落下途中に他の線材と干 渉しないよう，つめを切ってジャックから外れ易くした。発破の有 無および発破間隔は，PCにつないだ磁界切替えスイッチと発破間 隔コントローラによって制御される.PC からは発破間隔に応じて 信号が出力され，発破間隔コントローラ上のリレーが切り替わる仕 組みとなっている．このように，PC 制御で電磁ホルダの磁界を順 に消滅させ，発破による強制破断を再現することを可能とした。

構造部材のパラメータは以下の通りである. はり： $3 \mathrm{~cm} \times 3 \mathrm{~cm}$ 箱型部材, スパン長 $34 \mathrm{~cm}$, 破断臨界曲率 $2.4 \times 10^{-4} \mathrm{rad} / \mathrm{mm}$, 破断 臨界引張ひずみ $2.7 \times 10^{-4}$, 柱 : $4 \mathrm{~cm} \times 4 \mathrm{~cm}$ 箱型部材, スパン長 28 $\mathrm{cm}$, 破断臨界曲率 $3.1 \times 10^{-4} \mathrm{rad} / \mathrm{mm}$, 破断臨界引張ひずみ $3.0 \times 10^{-4}$, アルミニウム部材のヤング率 $70 \mathrm{GPa}$, ポアソン比 0.345. ただし, 破断臨界値については部材単体の実験によって事前に求め, 他のパ ラメータとともに数值解析に使用した．解析では構造减衰を無視し， 数値堿衰を適用した。時間増分は $0.01 \mathrm{~ms}$ とした。

開発した構造部材を用い，図 10 のような 6 層構造物を組み上げ た.このような繸長の構造物を解体する場合には, 外側に構造物が 倒壊して周辺に被害が生じないよう，一般的には上層部から順に折 り畳むように解体を進行させる，そこで，図のように上層部から 2 層ずつ交互に逆側へ倒し，“く”の字の形で落ちるように計画を立 てた. 3 段階に渡って発破することとし，その間隔を $0.2 \mathrm{~s}$ とした。 図 11 に実験結果と ASI-Gauss 法による解析結果を示す，倒壊する 構造物の部材位置が多少異なる部分も観察されるが，崩壊過程の時 刻歷は両者とも良好に一致し, また, 予測通りの崩壊モードが得ら れた。ささらに, 構造モデルの組み上げ誤差を考慮に入れても崩壊モ ードの再現性は高く，実験システムは十分に実用的であることが分 かった.

\section{4. 結論}

本研究では，ASI-Gauss 法を用いた爆破解体解析システムおよび 電磁デバイスを用いた爆破解体実験システムを開発し，6 層構造物 の爆破解体現象について比較・検討した，両者の結果は定量的にも 良好に一致し，解析システム，実験システムともに高い実用性があ ることが確認された，開発した構造部材はその性質上，弾塑性举動 を模擬することはできない，しかし，部材の弾性一脆性挙動を示す ことは可能で, 解体過程の大局的な挙動を模擬する上では十分であ ると考える. 今後, さらに大きな構造物に対し実験を行い, 両シス テムの有効性を検証していく予定である.
謝辞

本研究を遂行するにあたり, 独立行政法人日本学術振興会の科学 研究費補助金基盤研究 Al（課題番号：16206055）から援助を得た. ここに記し，謝意を表す。

\section{参考文献}

1) . G.T. Williams: Explosive demolition of tall buildings in inner city areas, Municipal Engineer, Vol. 7, No. 4, pp.163-173, 1990

2) E. Yarimer: Demolition by Controlled Explosion as a Dynamical Process, Structures under Shock and Impact, pp.411-416, 1989.

3）木下 雅敬，長谷川照美，松岡 栄，中川 浩二 : 発破による鉄筋コンクリート 構造物の解体に関する基礎的研究，土木学会論文集，第 403 号, VI-10, pp.173-182, 1989.

4) P.A. Cundall: A Computer Model for Simulating Progressive, Large-scale Movement in Blocky Rock System, Proceedings of the International Symposium on Rock Mechanics, II-8, pp. 129-136, 1971.

5) G.H. Shi and R.E. Goodman: Discontinuous Deformation Analysis, Proceedings of 25th U.S. Symposium on Rock Mechanics, pp. 269-277, 1984.

6) N. Tosaka, Y. Kasai and T. Honma: Computer Simulation for Felling Patterns of Building, Demolition Methods and Practice, pp.395-403, 1988.

7) M.Y. Ma, P. Barbeau and D. Penumadu: Evaluation of active thrust on retaining walls using DDA, Joumal of Computing in Civil Engineering, Vol. 1, pp.820-827, 1995.

8）磯部大吾郎，チョウミョウリン: ASトGans 法による世界贸易センタービルの飛行 機衙突解析,日本建築学会橉造系論文集，第600号, pp8388,20062.

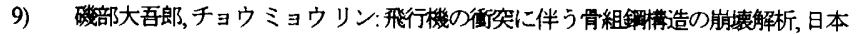
建築学会構造系論文集, 第 579 号,pp3946,20045.

10) Y. Toi and D. Isobe: Adaptively Shifted Integration Technique for Finite Element Collapse Analysis of Framed Structures, International Journal for Numerical Methods in Engineering, Vol. 36, pp.2323-2339, 1993.

11) D. Isobe and $Y$. Toi: Analysis of Structurally Discontinuous Reinforced Concrete Building Frames Using the ASI Technique, Computers and Structures, Vol.76, No.4, pp.471-481, 2000.

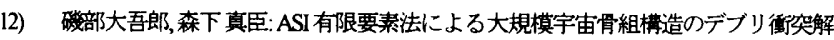
析,日本機诚学会論文集(A編)第64巻,第 627号,pp2726-2733,1998

13) D. Isobe and M. Tsuda: Seismic Collapse Analysis of Reinforced Concrete Framed Structures Using the Finite Element Method, Earthquake Engineering and Structural Dynamics, Vol.32, No.13, pp.2027-2046, 2003

14）都井裕：骨組棈造および回転対称シェル粠造の有限要素解析におうり Shifted Integration 法について, 日本造船学会論文集, 第 168 号, pp.357-369, 1990.

15) K. J. Bathe: Finite Element Procedures, Prentice Hall, 1996.

（2006年 4 月 10 日原稿受理，2006年10月23日採用決定） 